\title{
THE ESTIMATION OF HEAVY METALS IN SUBARNAREKHA RIVER AT MAU BHANDAR AND GALUDIH BARRAGE, JHARKHAND
}

\author{
Swetaleena Mishra, Ravinder Singh \\ University Department of Zoology, Kolhan University, Chaibasa, Jharkhand \\ Brajesh Kumar \\ Department of Chemistry, Tata College, Chaibasa, Jharkhand
}

\begin{abstract}
Heavy metal pollution deserves due concern as their exposure has been linked to developmental retardation, kidney damage, different types of cancers and even death in instances of very high exposure. Quantitative determination of heavy metals in the water samples of Subarnarekha River from two different sites has been carried out using Atomic Absorption Spectrophotometry. The analysis showed that the concentration of Heavy Metals is moderately high in the water sample at Mau Bhandar site as it is the industrial domain and this can be hazardous to both soil and water ecosystem as well as to the human population residing in the nearby areas.
\end{abstract}

Keywords - Atomic Absorption Spectrophotometry, Ecosystem, Geogenic process

\section{INTRODUCTION}

The high concentration of heavy metals in any ecosystems is an undesirable and a very serious issue for the environment as their toxicity can cause severe damage to the various ecological components. At present, heavy metal pollution is a burning issue. Its repercussions are such that the WHO has specially listed about ten metals that are raising environmental concerns like Mercury, Lead, Arsenic, Cobalt, Nickel, Zinc, Selenium, Silver, Antimony and Thallium.

We all know that the heavy metals occur in the crust of the earth naturally. Several geogenic as well as the anthropogenic activities result in the accumulation of heavy metals to a very toxic level. In this study, we have taken two sites in the Ghatsila sub-division of East Singbhum district. This region has several mining sites that have further escalated the problem of heavy metal pollution in the Subarnarekha river. The Copper mines of Rakha, Surda and Kendadih, the Uranium mines of Jadugoda, Bhatim, Turamdih, Narwah and Bagjata and the emerald mines of Gurabandha contribute to heavy metal pollution in this river. Their toxicity is a very serious issue since the heavy metals do not degrade as such in nature by natural processes. Subsequently, they accumulate in the environment in different niches and thus, in the various food chains. The vital aim of the present work is to estimate the concentration of different heavy metals present in the river Subarnarekha at the Mau Bhandar stretch and Galudih barrage.

\section{MATERIALS AND METHODS}

Site description - The Subarnarekha river flows over the states of India- Odisha, Jharkhand and West Bengal. It is amongst one of the longest flowing rivers in the eastern region that originates from the Nagri village in the Ranchi district of Jharkhand. The site of work is present just in the neighboring area of the Hindustan Copper Limited factory and the Galudih barrage where the Subarnarekha river flows. The HCL is a profound Copper producer of India that carries many activities like mining, smelting, refining and also manufacture the cast rods. The Galudih barrage has been built on the river Subarnarekha by the Water Resources Department of Jharkhand state Government basically for facilitating irrigation in the adjoining huge land areas. Because of the presence of several industries and numerous mining sites, heavy metal pollution has become a major concern and a primary environmental issue in these localities of East Singhbhum. Subarnarekha river receives heavy rainfall in the months of June- September during monsoon season.

2.1. Chemicals - Lead Nitrate, Nitric Acid, Copper Nitrate, Zinc Nitrate, Cadmium Chloride, Chromium Chloride and Ferrous Sulphate. Firstly, pre-concentration of samples was carried out and then the residue ware leached with $0.1 \mathrm{M}$ Nitric Acid $\left(\mathrm{HNO}_{3}\right)$. These chemicals were used for determination of the heavy metals present in the water samples from both the sites like Nickel, Lead, Cadmium, Copper, Cobalt, Iron and Zinc by Atomic Absorption Spectrophotometer (AAS).

2.2. Collection of samples - This study was performed in the pre-monsoon period that is from April- May and monsoon period that is from July- August seasons in the year 2017 and 2018. The water samples were collected in the 2-litres polypropylene bottles and labelled properly. Then $1.0 \mathrm{ml}$ of concentrated Nitric Acid was added to them for digestion and to avoid microbial activities. The samples were next boiled to 


\section{International Journal of Engineering Applied Sciences and Technology, 2019 Vol. 4, Issue 4, ISSN No. 2455-2143, Pages 84-86 \\ Published Online August 2019 in IJEAST (http://www.ijeast.com)}

one-fourth of their original volume. These solutions were then stored in the refrigerator for two weeks. Then $100 \mathrm{ml}$ of each water sample was filtered and then concentrated to $60 \mathrm{ml}$ solution in the $100 \mathrm{ml}$ standard flasks. To them $5 \mathrm{ml}$ of $\mathrm{HNO}_{3}$ was added. These samples were now analyzed for the presence of any heavy metals present in them by the use of AAS. This was done in accordance to the standard methods that were prescribed in the manual provided along with the AAS.

2.3. Instrumentation - The Atomic Absorption Spectroscopy is a modern analysis technology which helps in the measurement of concentration of the desired elements both qualitatively and quantitatively. When a light ray of measured wavelength falls on a free and ground-state atom, the atom then absorbs some amount of light so as to enter into the excited state and this mechanism is called atomic absorption. The AAS is used for analyzing the concentrations of metallic ions. The calibration curves were drawn using the standard solutions of metal ions that were prepared by following the procedures provided in the manual along with the instrument. Then three replicates of each experiment were carried out for further experimentation. The \% Relative Standard Deviation (RSD) was found to be less than 2 .

\section{RESULTS AND DISCUSSION}

The analysis of water samples from the two study sites show that the river Subarnarekha water has been found to be slightly pale yellowish in colour and possess slight odour as of Iron at Mau Bhandar site. In contrary, the river water at the Galudih barrage is nearly transparent in colour and odorless. The result clearly shows that the Subarnarekha water at the Mau Bhanadar stretch is comparatively more contaminated with heavy metals than at the Galudih barrage site.

Though, both the study sites are situated in a range of $7-8 \mathrm{kms}$, but the heavy metal contamination is less at the Galudih barrage site due to the fact that there are no major industrial activities over that place whereas Mau Bhandar is a prime industrial and mining site. The water at Galudih barrage carries the heavy metal pollutants from the industries present in Jamshedpur and as it flows it gets more polluted with the heavy metal $\mathrm{s}$ from the mining industries in Ghatsila. The analytical results of the different heavy metals found in the river water samples at the two sites are shown in the tabular form below.

At both the sites heavy metal concentration was found to be more during the post monsoon period probably due to the flooding of river from the Jamshedpur industrial region that carries loads of heavy metal pollutants with it. However, traces of the highly toxic metals like Cadmium and Arsenic were not found at these sites.

-Toxic effects of Heavy Metals:

i. Iron: Although normal quantity of Iron is essential for erythropoiesis, synthesis of haemoglobin, myoglobin and cytochromes, its presence in large quantities can cause haemochromatosis, which is a condition of excessive deposition of Iron causing damage of organs, leading to fibrosis. Increased Iron concentration in body can cause cardio-vascular diseases.

ii. Zinc: Zinc is responsible for maintaining a healthy immune system and is required for the normal growth and development. Long-term exposure to Zinc may result in the decreased absorption of Copper inside the body resulting in Copper deficiency. Excess Zinc may also trigger neuronal death (Klaassen, 2008).

iii. Copper: Long term copper exposure can produce many disorders like irritation of nose, mouth and eyes, stomach ache, dizziness, vomiting and diarrhea, and in severe exposure it may also cause endocrine disruption.

iv. Lead: Lead poisoning may cause development of anemia, disrupt functioning of kidneys, effect gastro intestinal tract.

The table shows the results of the analysis done in the present work together with the permissible range of heavy metal ions as defined by WHO.

Table 1: Analytical result of Heavy Metals in the water samples of Subarnarekha River, Mau Bhandar and Galudih Barrage.

\begin{tabular}{|c|c|c|c|c|c|c|}
\hline \multirow{2}{*}{$\begin{array}{l}\text { S/ } \\
\text { n } \\
\text { o. }\end{array}$} & \multirow[t]{2}{*}{ Metal } & \multicolumn{2}{|c|}{$\begin{array}{c}\text { Conc. Of } \\
\text { Metal (ppm) } \\
\text { (At Mau } \\
\text { Bhandar) } \\
\end{array}$} & \multicolumn{2}{|c|}{$\begin{array}{c}\text { Conc. Of Metal } \\
\text { (ppm) } \\
\text { (At Galudih } \\
\text { Barrage) } \\
\end{array}$} & \multirow{2}{*}{$\begin{array}{c}\text { Permis } \\
\text { sible } \\
\text { Conc. } \\
\text { by } \\
\text { WHO } \\
\text { (ppm) }\end{array}$} \\
\hline & & $\begin{array}{l}\text { Pre } \\
\text { Mon } \\
\text { soon }\end{array}$ & $\begin{array}{l}\text { Post } \\
\text { Mons } \\
\text { oon }\end{array}$ & $\begin{array}{c}\text { Pre } \\
\text { Mons } \\
\text { oon }\end{array}$ & $\begin{array}{c}\text { Post } \\
\text { Monso } \\
\text { on }\end{array}$ & \\
\hline 1 & Lead & 0.024 & 0.03 & 0.015 & 0.02 & 0.01 \\
\hline 2 & Copper & 2.05 & 2.02 & 2.01 & 2.02 & 2.0 \\
\hline 3 & Iron & 0.03 & 0.04 & 0.01 & 0.03 & 0.2 \\
\hline 4 & Zinc & 3.2 & 3.3 & 2.9 & 3.1 & 3.0 \\
\hline
\end{tabular}

Based on the concentration range and abundance, the estimated elements may be ranked in descending order as $\mathrm{Fe}>$ $\mathrm{Cu}>\mathrm{Zn}>\mathrm{Pb}$.

\section{CONCLUSION}

The presence of different heavy metals in higher concentrations in the aquatic ecosystems has many farreaching implications directly on the ecosystem of the water bodies and also indirectly on the population residing in the nearby areas. Heavy metals severely affect the vital organs such as kidneys and liver. The significance of heavy metals in ecotoxicology is due to the fact that they are highly toxic and persistent. Many studies show that heavy metals like Iron, Manganese, Chromium and Silver are phytotoxic at higher concentrations and may cause considerable amount of ecological damage to water, air and soil. Lead in particular, is toxic to the vital organs like brain, kidneys, heart and 


\section{International Journal of Engineering Applied Sciences and Technology, 2019 \\ Vol. 4, Issue 4, ISSN No. 2455-2143, Pages 84-86 \\ Published Online August 2019 in IJEAST (http://www.ijeast.com)}

reproductive system. Therefore, determination of heavy metal concentration has been given due importance in this study.

The presence of different heavy metals in moderately high concentration in the water sample from both sites indicate that the river water can have hazardous effects on the water and soil ecosystem and also on the human population nearby. Hence, continual assessment and enlightenment in this context is essential. Besides, it is really important that the Government should make policies for conservation of soil and water in this industrial belt of Jharkhand and measures should be taken for proper disposal of wastes from the industries. Industrialisation will not benefit the mankind unless it follows the path of sustainable development.

\section{REFERENCES}

1) Banerjee, S., Kumar, A., Maity, S. K. (2016). Seasonal variations in heavy metal contaminations in water Pnd sediments of Jamshedpur stretch of Subarnarekha river, India. Environmental earth sciences 75 (3), (Pg265).

2) Dubey, M.K. \& Verma, P.K. (2014). Assessment of heavy metals in drinking water in a tribal belt of Godda district (Santal Pargana), Jharkhand. Indian Journal of Environmental Sciences 18(1), (Pg29-32).

3) Gautam, S.K., Maharana, C., Sharma, D., Singh, A.K. (2015). Evaluation of groundwater quality in the Chotanagpur plateau region of Subarnarekha river basin, Jharkhand, India. Sustainability of Water Quality and Ecology 6, (Pg57-74).

4) Giri, S., Singh, A.K. (2014). Assessment of surface water quality using heavy metal pollution index in Subarnarekha River, India. Water Quality, Exposure and Health 5 (4), (Pg173-182).

5) Giri, S., Singh, A.K. \& Tewary, B.K. (2013). Source and distribution of metals in bed sediments of Subarnarekha river, India. Environmental Earth Sciences 70, (Pg3381).

6) J. Ramchander, B. Rajitha, G. Sunitha, E. Parveen, A. Anjaneyulu, J. Sunitha, Sayaji Rao. (2015). Quantitative Determination of Heavy Metals in Water Samples of Hyderabad in Telangana State. IOSR Journal of Applied Chemistry (IOSR-JAC), Vol.-8., issue 7, ver. I, (Pg1819).

7) Kulkarni, S. J., Dhokpande, S. R., Kaware, J. P. (2014). A Review on Studies on Sides Effects of Heavy Metals on Man and Environment. International Journal for Research in Applied Science and Engineering Technology (IJRASET), 2 (10), (Pg227-230).

8) Mahato, M.K., Singh, P.K., Tiwary, A.K. (2014). Evaluation of metals in mine water and assessment of heavy metal pollution index of east Bokaro coalfield area, Jharkhand. International Journal of Earth Sciences and Engineering 7(4), (Pg1611-1618).

9) Munshi, J.S.D., Mishra, A.N., Munshi, J.D., Aditya, A.K., \& Halder, P. (1998). Heavy metal pollution in Subarnarekha river: It's ecological impact on water quality and biota. Proceedings of the National Seminar on Environmental Biology, April 03-05.

10) Naz, Aliya, Chowdhuri, A., Mishra, B.K. \& Gupta, S.K. (2016). Metal pollution in water environment and the associated human health risk from drinking water: A case study of Sukinda chromite mine, India. Human and Ecological Risk Assessment 22(7), (Pg1433-1455).

11) Panda, U.C., Rath, P., Sahu, K.C., Majumdar, S., Sundaray, S.K. (2006). Environmental quantification of heavy metals in the Subarnarekha, estuary and near-shore environment, East coast of India. Asian Journal of Water, Environment and Pollution 3(2), (Pg85-92).

12) Patel, G., Mishra, N.S. (2013). Impact of anthropogenic and industrial activities on water quality and water selfpurification capacity of Subarnarekha river, Jharkhand. Environment and Ecology 31, (Pg1402-1407).

13) Paul, D. (2017). Heavy metal pollution of river Ganga: a review. Annals of Agrarian Science 15, (Pg278-286).

14) Priyadarshi, N. 2012. Effects of mining on environment in the state of Jharkhand, India. Environment and Geology.

15) Senapati, N.K., Sahu, K.C. (1996). Heavy metal distribution in Subarnarekha river, east coast of India. Indian Journal of Marine Sciences, 25, (Pg109-114).

16) S. Lee, J.W. Moon, H.S. Moon. (2003). Heavy metals in the bed and suspended sediments of Anyang river, Korea: implications for water quality. Environmental geochemistry and health 25 (4), (Pg433-452).

17) Upadhyay, A.K., Gupta, K.K., Sircar, J.K., Deb, M.K., Mundhara, G.L. (2006). Heavy metals in freshly deposited sediments of river Subarnarekha, India. Environmental Geology 50 (3), (Pg397-403).

18) Verma. R., Dwivedi, P. (2011). Heavy Metal Water Pollution-A Case Study, Recent Research in Science and Applications 2 (6), (Pg434-439). 